\title{
Asupan Serat Sebagai Faktor Dominan Obesitas Perempuan Pralansia
}

\section{Fiber Intake As Dominant Factor Of Middle Aged Women Obesity}

\author{
Fauza Rizqiya ${ }^{1}$, Ahmad Syafiq ${ }^{2}$ \\ ${ }^{1}$ Fakultas Kedokteran dan Kesehatan Universitas Muhammadiyah Jakarta \\ ${ }^{2}$ Fakultas Kesehatan Masyarakat Universitas Indonesia \\ (fauza.rizqiya@umj.ac.id, asq69@yahoo.co.uk) \\ Jl. Cempaka Putih Tengah XXVII No.46 Jakarta Pusat)
}

\begin{abstract}
ABSTRAK
Prevalensi obesitas pada perempuan pralansia semakin meningkat, padahal obesitas berdampak terhadap terjadinya penyakit degeneratif sehingga perlu ditanggulangi. Penelitian ini bertujuan untuk mencari factor dominan yang berhubungan dengan obesitas menurut persen lemak tubuh perempuan pralansia. Penelitian ini merupakan penelitian crosssectional. Responden merupakan 134 perempuan pralansia di Posbindu terpilih di Pancoran Mas, Depok. Data persen lemak tubuh diambil dengan menggunakan alat bioelectrical impedance analysis (BIA), data asupan dengan menggunakan formulir recall 2 x 24 jam, dan faktor lainnya dengan menggunakan pertanyaan pada kuesioner. Data dianalisis dengan menggunakan regresi logistik untuk memperoleh faktor dominan yang berhubungan dengan obesitas pralansia. Faktor dominan yang berhubungan dengan obesitas perempuan pralansia adalah asupan serat (OR=3,9; 95\% CI: 1,4-10,8). Penelitian ini menunjukkan bahwa asupan serat yang rendah dapat memicu obesitas pada perempuan pralansia dan memerlukan program yang sesuai yang membuat asupan serat pada perempuan pralansia meningkat.
\end{abstract}

\section{Kata Kunci : Asupan Serat; Obesitas; Perempuan Pralansia.}

\begin{abstract}
The prevalence of obesity on middle aged women keeps increasing and needs to be tackled because of degenerative disease as the result. This research aims to find dominant factors related to obesity according to body fat percentage on middle aged women. This study was quantitative with cross-sectional design. Subjects were 134 middle aged women in Selected Posbindu in Pancoran Mas, Depok. Body fat percentage of respondents were taken by using bioelectrical impedance analysis (BIA), food intake data taken by $2 \times 24$ hour recall, and other factors taken by using questions on the questionnaire. Data was analyzed by using logistic regression to asess dominant factor related to middle aged women obesity. Dominant factor that associated with middle aged obesity was fiber intake (OR=3,9; 95\% CI: 1,4-10,8). This study implies that low fiber intake can lead middle aged women to obesity and needs optimizing relevant programs that can make fiber intake among middle aged women increasing.
\end{abstract}

Keywords : Fiber Intake; Obesity;, Middle Aged Woman. 


\section{PENDAHULUAN}

Obesitas memiliki dampak terhadap terjadinya penyakit jantung koroner, diabetes mellitus, hipertensi, dislipidemia, dan gagal jantung kongestif (Zamboni et al., 2005). Dewasa ini, prevalensi obesitas meningkat secara cepat bahkan pada kelompok pralansia (Zamboni, et al., 2005). Di Indonesia, prevalensi obesitas lansia cenderung meningkat. Pada tahun 2010, terdapat rata- rata 11,4\% penduduk usia 45 tahun ke atas yang mengalami obesitas, kemudian pada tahun 2013 meningkat menjadi 14,5\% (Balitbangkes, 2014).

Serat memiliki hubungan terhadap terjadinya obesitas. Banyak penelitian yang membuktikan ada hubungan antara asupan serat dengan terjadinya obesitas. Salah satunya yaitu penelitian yang dilakukan oleh Bierketdt, et al. (2000) yang menemukan bahwa penambahan tinggi serat dalam diet rendah kalori secara signifikan menambah penurunan berat badan, dimana kelompok yang diberi placebo turun sebanyak 5,8 kilogram dan mereka yang diberi tambahan serat turun lebih banyak yaitu 8 kilogram.

Selanjutnya, asupan kalsium turut berkontribusi dalam terjadinya obesitas pada seseorang. Asupan kalsium yang rendah memicu terjadinya obesitas. Asupan kalsium yang rendah memicu terjadinya obesitas (Soares, Ping-delfos, \& Ghanbari, 2011). Hal ini pun dibuktikan dalam beberapa penelitian. Penelitian di Jerman membuktikan bahwa ada perubahan penurunan berat badan selama 24 bulan terhadap responden yang mengalami obesitas dengan pemberian kalsium (Michael \& Sharon, 2004).

Asupan karbohidrat, protein dan lemak juga turut berkontribusi dalam terjadinya obesitas pada pralansia. Sebuah penelitian di Swedia pada usia middle aged menyatakan bahwa ada hubungan yang signifikan antara asupan zat gizi makro dengan terjadinya obesitas (Sonestedt et al., 2009). Penyebab lain terjadinya obesitas adalah rendahnya aktifitas fisik. Sebuah penelitian kohort terhadap para lansia di Inggris menyatakan bahwa responden yang memiliki aktifitas rendah seperti menonton televisi setiap hari memiliki risiko 1,39 kali lebih besar dibanding dengan mereka yang memiliki aktifitas fisik tinggi (Hamer, Weiler, \& Stamatakis, 2014).

Singkatnya durasi tidur malam seseorang juga turut berkontribusi dalam terjadinya obesitas. Penelitian di Wisconsin terhadap pekerja usia 30-60 tahun yang menyatakan bahwa ada hubungan yang signifikan antara durasi tidur malam kurang dari 7,7 jam per hari dengan meningkatnya indeks massa tubuh (Taheri, Lin, Austin, Young, \& Mignot, 2004). Penelitian lain di Quebec juga memberikan hasil yang sama. Persen lemak tubuh responden yang tidur 5-6 jam per hari cenderung lebih tinggi daripada mereka yang tidur 
Fauza Rizqiya, Ahmad Syafiq : Fiber Intake As Dominant Factor Of Middle ....

7-8 jam per hari (Chaput, Despre, Despre, Bouchard, \& Tremblay, 2007). Lebih lanjut lagi, penelitian di Australia membuktikan bahwa ada hubungan antara waktu tidur $<6$ jam pada malam hari dengan kejadian obesitas pada responden usia middle aged (Magee, Iverson, \& Caputi, 2010).

Tingkat pendidikan juga berhubungan dengan terjadinya obesitas pada pralansia. Pada negara berkembang seperti Indonesia, penduduk yang memiliki tingkat pendidikan tinggi lebih banyak mengalami obesitas dibanding dengan penduduk yang memiliki tingkat pendidikan rendah (Balitbangkes, 2014). Hal yang sama terjadi pada tingkat pendapatan. Pada negara berkembang seperti Indonesia dan Thailand, penduduk yang memiliki pendapatan tinggi cenderung lebih banyak mengalami obesitas dibandingkan dengan mereka yang memiliki pendapatan rendah (Riskesdas, 2014; Seubsman et al., 2010).

Penelitian ini dilakukan di Kecamatan Pancoran Mas karena di kecamatan ini populasi lansia dan jumlah Posbindu memiliki jumlah tertinggi dibandingkan kecamatan lainnya. Penelitian ini juga bertujuan untuk mengetahui faktor dominan obesitas perempuan pralansia di Kecamatan Pancoran Mas Depok.

\section{METODE}

Penelitian ini menggunakan metode penelitian kuantitatif dengan desain cross sectional. Data yang dianalisis adalah hubungan dua arah antara variabel independen (asupan serat, asupan kalsium, asupan karbohidrat, asupan protein, asupan lemak, durasi tidur malam, dan aktivitas fisik) dengan variabel dependen (obesitas). Selain itu, penelitian ini juga menganalisis faktor apa yang paling dominan dalam hubungannya dengan obesitas. Penelitian ini dilaksanakan di 10 Posbindu pada wilayah Kecamatan Pancoran Mas, Depok.

Populasi dalam penelitian ini adalah 2239 pralansia di Kecamatan Pancoran Mas Depok. Sementara itu populasi studi dari penelitian ini ada sebanyak 957 pralansia berjenis kelamin perempuan. Setelah itu, subjek yang sesuai kebutuhan penelitian (eligible subject) ditentukan dengan menggunakan kriteria inklusi dan eksklusi. Sampel dalam penelitian ini adalah seluruh perempuan usia 45-59 tahun yang merupakan anggota Posbindu di Kecamatan Pancoran Mas, Depok, yang hadir pada saat dilakukannya pengambilan data dan memenuhi kriteria inklusi. Kriteria inklusi dalam penelitian ini yaitu seluruh perempuan usia 45-59 tahun (pralansia). Adapun kriteria eksklusi dari penelitian ini diantaranya yaitu perempuan pralansia yang memiliki masalah fisik untuk 
berdiri, menggenggam tangan, mendengar dan menjawab pertanyaan. Berdasarkan kriteria tersebut maka jumlah sampel dalam penelitian ini adalah 134 orang.

Pada pelaksanaan pengumpulan data, tim yang terdiri dari peneliti dan enumerator datang ke Posbindu terpilih untuk mengambil data, dengan prosedur sebagai berikut. Seluruh responden dikumpulkan dalam satu tempat untuk memperoleh penjelasan mengenai penelitian yang akan dilakukan. Kemudian responden mengisi inform consent untuk menyatakan kesediaan dalam menjadi responden penelitian. Selanjutnya, responden menuju pos pertama, yaitu pos antropometri untuk diambil pengukuran berat badan dengan menggunakan timbangan injak elektrik, tinggi badan dengan menggunakan microtoise, dan persen lemak tubuh dengan menggunakan BIA.

Setelah selesai dari pos pertama, responden berpindah ke pos kedua. Pada pos ini responden diwawancara recall 24 jam hari pertama dan pertanyaan kuesioner mengenai durasi tidur malam, aktivitas fisik, tingkat pendidikan, dan tingkat pendapatan. Selanjutnya, enumerator diantar oleh kader mendatangi rumah responden untuk mewawancara recall 24 jam hari kedua. Setelah seluruh data responden terkumpul, penulis melakukan pemeriksaan kuesioner yang telah diisi untuk menghindari kesalahan pengisian.

Data yang digunakan merupakan data primer berupa data antropometri seperti tinggi badan, berat badan dan persen lemak tubuh. Selain itu, data primer lainnya berupa data asupan makanan, aktivitas fisik, tingkat pendidikan dan tingkat pendapatan. Data tinggi badan diperoleh dengan menggunakan berat badan, data berat badan diperoleh dengan menggunakan timbangan injak digital, dan data persen lemak tubuh diperoleh dengan menggunakan Bioelectrical Impedance Analysis (BIA). Kemudian data asupan makanan berupa asupan serat, karbohidrat dan protein diperoleh dengan menggunakan metode recall 2 × 24 jam.

Analisis data yang dilakukan berupa analisis univariat, bivariat dan multivariat. Analisis univariat dilakukan untuk menggambarkan distribusi frekuensi variabel terikat maupun bebas, seperti obesitas, asupan serat, asupan kalsium, asupan karbohidrat, asupan protein, asupan lemak, durasi tidur malam, aktivitas fisik, tingkat pendidikan dan tingkat pendapatan. Selanjutnya, analisis bivariat dilakukan untuk mengetahui hubungan antara dua variabel, yaitu variabel bebas (asupan serat, asupan kalsium, asupan karbohidrat, asupan protein, asupan lemak, durasi tidur malam, aktivitas fisik, tingkat Pendidikan dan tingkat pendapatan) dengan variabel terikat (obesitas). Analisis bivariat ini dilakukan menggunakan uji chi square. Selanjutnya, Analisis multivariat dalam penelitian ini 
Fauza Rizqiya, Ahmad Syafiq : Fiber Intake As Dominant Factor Of Middle ....

dilakukan dengan menggunakan regresi logistik ganda model prediksi, dimana pada pemodelan ini semua variabel dianggap penting sehingga dapat dilakukan estimasi beberapa koefisien regresi logistik sekaligus

\section{HASIL}

\section{Tabel 1. Rekapitulasi Hasil Univariat}

\begin{tabular}{|c|c|c|c|}
\hline Variabel & Presentase & $\mathbf{n}$ & Mean \pm SD \\
\hline Obesitas & & & $34,9 \pm 4,7$ \\
\hline $\mathrm{Ya}$ & 64,9 & 87 & \\
\hline Tidak & 35,1 & 47 & \\
\hline Asupan Serat & & & $34,8 \pm 24,4$ \\
\hline Kurang & 85,8 & 115 & \\
\hline Cukup & 14,2 & 19 & \\
\hline Asupan Kalsium & & & $34,7 \pm 26,8$ \\
\hline Kurang & 88,8 & 119 & \\
\hline Cukup & 11,2 & 15 & \\
\hline Asupan Karbohidrat & & & $57,3 \pm 23,2$ \\
\hline Cukup & 17,9 & 24 & \\
\hline Kurang & 82,1 & 110 & \\
\hline Asupan Protein & & & $69,3 \pm 33,2$ \\
\hline Cukup & 38,1 & 51 & \\
\hline Kurang & 61,9 & 83 & \\
\hline Asupan lemak & & & $56,5 \pm 27,4$ \\
\hline Cukup & 20,9 & 28 & \\
\hline Kurang & 79,1 & 106 & \\
\hline Durasi Tidur Malam & & & $5,82 \pm 1,2$ \\
\hline Singkat & 47,0 & 63 & \\
\hline Lama & 53,0 & 71 & \\
\hline Aktivitas Fisik & & & $163,7 \pm 46,5$ \\
\hline Tidak Aktif & 69,4 & 93 & \\
\hline Aktif & 30,6 & 41 & \\
\hline \multicolumn{4}{|l|}{ Tingkat Pendidikan } \\
\hline$\geq$ SMA & 35,8 & 48 & \\
\hline SMP & 25,4 & 34 & \\
\hline$\leq \mathrm{SD}$ & 38,8 & 52 & \\
\hline \multicolumn{4}{|l|}{ Tingkat Pendapatan } \\
\hline$\geq \mathrm{UMK}$ & 20,9 & 28 & \\
\hline$\leq \mathrm{UMK}$ & 79,1 & 106 & \\
\hline
\end{tabular}

Tabel 1 menunjukkan gambaran obesitas, asupan serat, asupan kalsium, asupan karbohidrat, asupan protein, asupan lemak, durasi tidur malam, aktivitas fisik, tingkat Pendidikan dan tingkat pendapatan. Berdasarkan tabel 1, dapat dilihat bahwa 64,9\% responden memiliki status gizi obesitas. Sementara itu, ada sebanyak 85,8\% responden memiliki asupan serat yang kurang. Selanjutnya, sebanyak 88,8\% responden memiliki asupan karbohidrat yang cukup, 17,9\% responden memiliki asupan protein yang cukup, dan 20,9\% responden memiliki asupan lemak yang cukup. Lebih lanjut lagi, pada tabel 1 juga dapat dilihat ada sebanyak $47 \%$ responden yang memiliki durasi tidur singkat, 
69,4\% responden tidak aktif dalam aktivitas fisik. Selanjutnya, ada sebanyak 38,8\% responden berpendidikan $\leq$ SD dan 79,1\% responden berpenghasilan $<$ UMK.

\section{Tabel 2. Rekapitulasi Hasil Bivariat}

\begin{tabular}{|c|c|c|c|c|c|c|}
\hline \multirow[t]{3}{*}{ Variabel } & \multicolumn{4}{|c|}{ Obesitas } & \multirow{3}{*}{$\begin{array}{c}\text { OR } \\
(95 \% \mathrm{CI})\end{array}$} & \multirow[t]{3}{*}{ P-value } \\
\hline & \multicolumn{2}{|c|}{ Ya } & \multicolumn{2}{|c|}{ Tidak } & & \\
\hline & $\mathrm{n}$ & $\%$ & $\mathrm{n}$ & $\%$ & & \\
\hline Asupan Serat & & & & & $3,918(1,423-10,793)$ & \\
\hline Kurang & 80 & 69,6 & 35 & 30,4 & & 0,012 \\
\hline Cukup & 7 & 36,8 & 12 & 63,2 & & \\
\hline Asupan Kalsium & & & & & $1,268(0,422-3,810)$ & 0,891 \\
\hline Kurang & 78 & 65,5 & 41 & 34,5 & & \\
\hline Cukup & 9 & 60,0 & 6 & 40,0 & & \\
\hline Asupan Karbohidrat & & & & & $1,388(0,530-3,632)$ & 0,665 \\
\hline Cukup & 17 & 70,8 & 7 & 29,2 & & \\
\hline Kurang & 70 & 63,6 & 40 & 36,4 & & \\
\hline Asupan Protein & & & & & $1,304(0,622-2,733)$ & 0,605 \\
\hline Cukup & 35 & 68,6 & 16 & 31,4 & & \\
\hline Kurang & 52 & 62,7 & 31 & 37,3 & & \\
\hline Asupan Lemak & & & & & $0,965(0,404-2,304)$ & 1,000 \\
\hline Cukup & 18 & 64,3 & 10 & 35,7 & & \\
\hline Kurang & 69 & 65,1 & 37 & 34,9 & & \\
\hline Durasi Tidur Malam & & & & & $1,319(0,646-2,696)$ & 0,562 \\
\hline Singkat & 43 & 68,3 & 20 & 31,7 & & \\
\hline Lama & 44 & 62,0 & 17 & 38,0 & & \\
\hline Aktivitas Fisik & & & & & $0,581(0,259-1,301)$ & 0,258 \\
\hline Tidak Aktif & 57 & 61,3 & 36 & 38,7 & & \\
\hline Aktif & 30 & 73,2 & 11 & 26,8 & & \\
\hline Tingkat Pendidikan & & & & & & \\
\hline$\geq$ SMA & 38 & 79,2 & 10 & 20,8 & 2,375 & 0,058 \\
\hline SMP & 17 & 50,0 & 17 & 50,0 & 0,625 & 0,292 \\
\hline$\leq \mathrm{SD}$ & 32 & 61,5 & 20 & 38,5 & & \\
\hline Tingkat Pendapatan & & & & & $2,313(0,865-6,185)$ & 0,139 \\
\hline$\geq \mathrm{UMK}$ & 22 & 78,6 & 6 & 21,4 & & \\
\hline$<\mathrm{UMK}$ & 65 & 61,3 & 41 & 38,7 & & \\
\hline
\end{tabular}

Berdasarkan Tabel 2 dapat dilihat bahwa asupan serat adalah variabel yang berhubungan dengan obesitas. Variabel independen lainnya seperti asupan kalsium, asupan karbohidrat, asupan protein, asupan lemak, durasi tidur, aktivitas fisik, tingkat Pendidikan dan tingkat pendapatan tidak memiliki hubungan yang signifikan dengan obesitas. 
Fauza Rizqiya, Ahmad Syafiq : Fiber Intake As Dominant Factor Of Middle ....

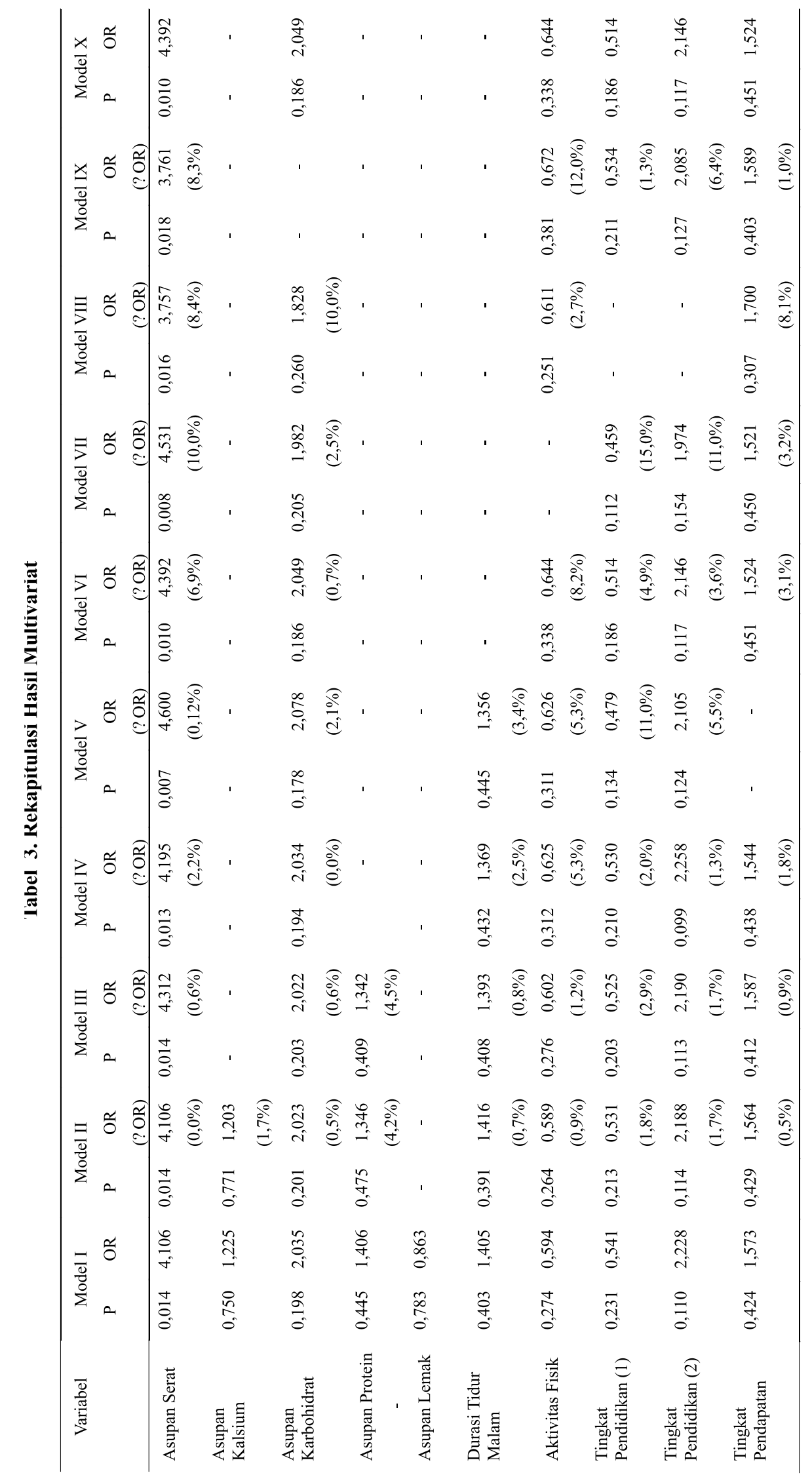


Tabel 3 menunjukkan rekapitulasi hasil analisis multivariat. Berdasarkan analisis multivariat diperoleh hasil variabel yang berhubungan bermakna dengan obesitas yaitu asupan serat. Sementara itu, variabel asupan karbohidrat, aktivitas fisik, tingkat pendidikan dan tingkat pendapatan menjadi variabel confounding. Hasil analisis didapatkan Odds ratio (OR) dari variabel asupan serat adalah 4,392 artinya perempuan pralansia yang asupan seratnya kurang akan memiliki risiko untuk mengalami obesitas sebesar 4 kali lebih tinggi dibandingkan perempuan pralansia yang asupan seratnya cukup setelah dikontrol variabel asupan karbohidrat, aktivitas fisik, tingkat pendidikan, dan tingkat pendapatan. Melalui hasil ini dapat disimpulkan bahwa asupan serat merupakan variabel yang paling dominan dalam hubungannya dengan kejadian obesitas pada perempuan pralansia di Posbindu terpilih pada Kecamatan Pancoran Mas Depok.

\section{PEMBAHASAN}

Hasil dari penelitian menunjukkan bahwa ada hubungan antara asupan serat dengan obesitas. Hasil ini sesuai dengan hipotesis awal mengenai adanya hubungan antara asupan serat dengan obesitas. Hasil ini sejalan dengan penelitian He, et al. (2004) yang menyatakan bahwa peningkatan asupan sayuran dan buah buahan berhubungan dengan menurunnya risiko obesitas pada wanita usia pralansia secara signifikan. Teori menyebutkan bahwa asupan serat dapat mencegah terjadinya obesitas dengan cara memperlama rasa kenyang, menurunkan absorpsi zat gizi makro, dan mengubah pengeluaran hormon di usus (Slavin, 2005). Berdasarkan hasil pendataan asupan serat, sebagian besar perempuan pralansia di Kecamatan Pancoran Mas memiliki asupan serat yang kurang, jarang dari mereka mengonsumsi sayuran dan buah. Sebagian besar dari mereka mendapat asupan serat dari kandungan serat yang ada dalam karbohidrat.

Hasil penelitian selanjutnya yaitu tidak ada hubungan asupan kalsium dengan obesitas. Hasil ini tidak sesuai dengan hipotesis awal mengenai adanya hubungan antara asupan kalsium dengan obesitas. Teori menyatakan bahwa rendahnya asupan kalsium berhubungan dengan massa lemak tubuh yang lebih banyak (Song \& Sergeev, 2012). Hubungan ini terjadi melalui cara asupan kalsium yang rendah mengoptimalkan penyerapan lemak di usus karena pembentukan sabun asam lemak yang dapat berfungsi mengganggu penyerapan lemak di tubuh menjadi sedikit (Song \& Sergeev, 2012). Akibatnya, banyak lemak yang diserap dan dalam jumlah yang berlebih secara terus menerus akan menyebabkan obesitas. Tidak bermaknanya variabel asupan kalsium ini dapat disebabkan oleh hampir semua responden memiliki asupan kalsium yang kurang, 
yaitu sebanyak 88,8\%. Mereka yang memiliki asupan kalsium kurang tersebar baik di status gizi obesitas maupun tidak.

Pada penelitian ini menghasilkan tidak ada hubungan antara asupan karbohidrat, protein dan lemak dengan obesitas. Teori menyatakan bahwa asupan karbohidrat yang tinggi menyebabkan terjadinya obesitas (Rathnayake, Roopasingam, \& Dibley, 2014). Asupan karbohidrat yang tinggi diubah menjadi lemak di hati. Lemak ini kemudian dibawa ke sel lemak yang dapat menyimpan lemak dalam jumlah yang sangat banyak (Sonestedt et al., 2009). Sementara itu, protein yang berlebihan dalam tubuh akan mengalami deaminase, nitrogen dikeluarkan dari tubuh dan sisa ikatan karbon akan diubah menjadi lemak dan disimpan di dalam tubuh ((Vinknes et al., 2011). Simpanan lemak yang banyak ini akan menyebabkan obesitas. Hal yang sama juga terjadi pada variabel lemak, yang menghasilkan tidak ada hubungan signifikan antara asupan lemak dengan obesitas. Tidak bermaknanya variabel asupan karbohidrat, protein dan lemak ini dapat disebabkan oleh asupan rerata responden yang kurang dari cut off point kecukupan karbohidrat, protein dan lemak. Selain itu, pada usia pralansia massa lemak tubuh cenderung meningkat seiring dengan bertambahnya usia.

Perihal durasi tidur, hasil menunjukkan tidak ada hubungan dengan obesitas. Menurut teori, durasi tidur yang pendek berhubungan dengan distribusi lemak tubuh dan meningkatnya persen lemak tubuh (Patel et al., 2008). Hal ini berkaitan dengan menurunnya kadar hormon leptin sekaligus meningkatnya hormon ghrelin. Menurunnya kadar hormon leptin berakibat pada meningkatnya nafsu makan, ditambah dengan waktu tidur yang cepat sehingga semakin banyaknya waktu yang tersedia untuk makan yang pada akhirnya keadaan tersebut akan membuat seseorang menjadi obesitas (Garaulet et al., 2011). Tidak bermaknanya variabel durasi tidur ini dapat disebabkan oleh sebagian besar perempuan lansia lebih memilih mengisi waktu malam terjaganya dengan beribadah, seperti salat tahajjud dan mengaji dibanding dengan makan.

Perihal aktivitas fisik, penelitian ini menghasilkan bahwa tidak ada hubungan antara aktifitas fisik dengan obesitas. Hasil penelitian ini berbanding terbalik dengan teori yang ada. Hasil penelitian lain menyebutkan bahwa rendahnya aktivitas fisik dapat mengakibatkan obesitas (Hamer et al., 2014). Hal ini disebabkan oleh responden yang memiliki aktivitas fisik tinggi baru saja memulai kegiatan rutin olahraga bersamaan dengan dilaksanakannya Posbindu, dimana pada saat muda responden jarang melakukan aktivitas fisik. Selain itu, aktivitas sosial seperti arisan dan pengajian juga termasuk dalam komponen aktivitas fisik, dimana dalam kegiatan aktifitas sosial pasti ada 
makanan, yang memungkinkan responden mengiringi aktivitas fisik dengan kegiatan makan.

Perihal pendidikan, hasil dari penelitian menunjukkan bahwa tidak ada hubungan antara tingkat Pendidikan dengan obesitas. Teori menyatakan bahwa tingkat pendidikan sejalan dengan tingginya tingkat pendapatan yang membuat semakin luasnya pemilihan makanan, termasuk makanan yang tinggi kalori dan berlemak (Sassi, Devaux, Church, Cecchini, \& Borgonovi, 2009). Perbedaan hasil penelitian ini dapat terjadi karena tingkat pendidikan tidak diikuti dengan pengetahuan gizi, sehingga terjadi kesalahan dalam pemilihan dan pengolahan makanan.

Hasil yang tidak berhubungan juga terdapat pada variabel tingkat pendapatan dengan obesitas. Hasil ini tidak sesuai dengan hipotesis awal mengenai hubungan antara tingkat pendapatan dengan obesitas. Hal ini sejalan dengan hasil penelitian Inandia (2012) yang menyatakan bahwa tidak ada hubungan bermakna dengan p value sebesar 0,776. Namun, hasil yang berbeda terdapat pada penelitian di Jakarta Timur, dimana ada hubungan yang signifikan antara tingkat pendapatan dengan obesitas (Putriani, 2009). Tidak bermaknanya variabel tingkat pendapatan ini disebabkan oleh tingginya pendapatan tidak diiringi dengan pengetahuan gizi yang baik sehingga dapat terjadi kesalahan dalam pemilihan dan pengolahan makanan, dimana responden cenderung untuk memilih makanan yang cepat saji, rendah serat serta mengolah makanan dengan cara digoreng.

Faktor dominan yang berhubungan dengan obesitas dalam penelitian ini adalah asupan serat dengan Odds ratio (OR) dari variabel asupan serat adalah 4,346, artinya perempuan pralansia yang asupan seratnya kurang akan memiliki risiko untuk mengalami obesitas sebesar 4 kali lebih tinggi dibandingkan perempuan pralansia yang asupan seratnya cukup setelah dikontrol variabel asupan karbohidrat, aktivitas fisik, tingkat pendidikan, dan tingkat pendapatan. Hasil ini sejalan dengan penelitian Tucker \& Thomas (2009) yang menyatakan ada hubungan antara asupan serat dengan obesitas perempuan pralansia.

\section{SIMPULAN}

Berdasarkan hasil analisis penelitian, dapat disimpulkan bahwa variabel dominan yang berhubungan dengan obesitas perempuan pralansia adalah asupan serat setelah dikontrol oleh variabel asupan karbohidrat, aktivitas fisik, tingkat pendidikan, dan tingkat pendapatan. 
Fauza Rizqiya, Ahmad Syafiq : Fiber Intake As Dominant Factor Of Middle ....

\section{UCAPAN TERIMA KASIH}

Ucapan terima kasih kami sampaikan kepada Ahmad Syafiq sebagai pembimbing dan

Fakultas Kedokteran dan Kesehatan Universitas Muhammadiyah Jakarta atas dukungan kepada peneliti.

\section{DAFTAR PUSTAKA}

Balitbangkes. 2011. Riset Kesehatan Dasar 2010. Jakarta: Kementerian Kesehatan RI.

Balitbangkes. 2014. Riset Kesehatan Dasar 2013. Jakarta: Kementerian Kesehatan RI.

Birketdt, G.S., et al. 2000. Long Term Effect of Fibre Supplement and Reduced energy Intake on Body Weight and Blood Lipids in Overweight Subjects. Acta Med, 43, 129-132.

Chaput, J., Despre, J., Despre, J., Bouchard, C., \& Tremblay, A. (2007). Short Sleep Duration is Associated with Reduced Leptin Levels and Increased Adiposity Results from the Que ' bec Family Study.

Garaulet, M., Ortega, F. B., Ruiz, J. R., Rey-López, J. P., Béghin, L., Manios, Y., ... Moreno, L. A. (2011). Short sleep duration is associated with increased obesity markers in European adolescents: Effect of physical activity and dietary habits. the HELENA study. International Journal of Obesity, 35(10), 1308-1317. https://doi.org/10.1038/ijo.2011.149

Hamer, M., Weiler, R., \& Stamatakis, E. (2014). Watching sport on television, physical activity, and risk of obesity in older adults. BioMed Central, 14(10), 2-5.

He, K., Hu, F. B., Colditz, G. A., Manson, J. E., Willett, W. C., \& Liu, S. (2004). Changes in intake of fruits and vegetables in relation to risk of obesity and weight gain among middle-aged women. International Journal of Obesity, 28(12), 15691574. https://doi.org/10.1038/sj.ijo.0802795

Magee, C. A., Iverson, D. C., \& Caputi, P. (2010). Sleep duration and obesity in middleaged Australian adults. Obesity, 18(2), 420-421. https://doi.org/10.1038/oby.2009.373

Michael, B., \& Sharon, L. (2004). Dietary Calcium and Dairy Modulation of Adiposity and Obesity Risk.

Murakami, K., et al. (2006). No relation between intakes of calcium and dairy products and body mass index in Japanese women. Nutrition, 22, 490-495.

Patel, S. R., Blackwell, T., Redline, S., Ancoli-Israel, S., Cauley, J. A., Hillier, T. A., ... Stone, K. L. (2008). The association between sleep duration and obesity in older adults. International Journal of Obesity, 32(12), 1825-1834. https://doi.org/10.1038/ijo.2008.198

Pedersen, Sue D., et al. Obesity as A Health Risk, dalam Erdman, John W., Jr., et al. (2012). Present Knowledge in Nutrition $10^{\text {th }}$ edition. USA: Wiley- Blackwell.

Putriani, S.D. (2009). Hubungan antara Serat, Aktivitas Fisik dan Kebiasaan Merokok dengan Obesitas Abdominal pada Lansia di Posyandu Lansia Kelurahan Kramat Jati II Jakarta Timur Tahun 2009. [Skripsi]. Program Sarjana FKM UI, Depok.

Rathnayake, K. M., Roopasingam, T., \& Dibley, M. J. (2014). High carbohydrate diet and physical inactivity associated with central obesity among premenopausal housewives in Sri Lanka. BMC Research Notes, 7(1), 1-7. https://doi.org/10.1186/1756-0500-7-564

Sassi, F., Devaux, M., Church, J., Cecchini, M., \& Borgonovi, F. (2009). Education and obesity in four OECD countries. OECD Health Working Papers, 46(39), 1-47. https://doi.org/10.1787/223688303816 
Seubsman, S., Lim, L. L.-Y., Banwell, C., Sripaiboonkit, N., Kelly, M., Bain, C., \& Sleigh, A. C. (2010). Socioeconomic Status, Sex, and Obesity in a Large National Cohort of 15-87-Year-Old Open University Students in Thailand. Journal of Epidemiology, 20(1), 13-20. https://doi.org/10.2188/jea.JE20090014

Slavin, J. L. (2005). Dietary fiber and body weight. Nutrition, 21(3), 411-418. https://doi.org/10.1016/j.nut.2004.08.018

Soares, M. J., Ping-delfos, W. C. S., \& Ghanbari, M. H. (2011). Calcium and vitamin D for obesity : a review of randomized controlled trials. European Journal of Clinical Nutrition, 65(9), 994-1004. https://doi.org/10.1038/ejcn.2011.106

Sonestedt, E., Roos, C., Gullberg, B., Ericson, U., Wirfält, E., \& Orho-Melander, M. (2009). Fat and carbohydrate intake modify the association between genetic variation in the FTO genotype and obesity. American Journal of Clinical Nutrition, 90(5), 1418-1425. https://doi.org/10.3945/ajcn.2009.27958

Song, Q., \& Sergeev, I. N. (2012). Calcium and vitamin D in obesity Nutrition Research Reviews, 25, 130-141. https://doi.org/10.1017/S0954422412000029

Taheri, S., Lin, L., Austin, D., Young, T., \& Mignot, E. (2004). Short sleep duration is associated with reduced leptin, elevated ghrelin, and increased body mass index. PLoS Medicine, 1(3), 210-217. https://doi.org/10.1371/journal.pmed.0010062

Tucker, L. A., \& Thomas, K. S. (2009). Increasing Total Fiber Intake Reduces Risk of Weight and Fat Gains in Women. Journal of Nutrition, 139(3), 576-581. https://doi.org/10.3945/jn.108.096685

Vinknes, K. J., de Vogel, S., Elshorbagy, A. K., Nurk, E., Drevon, C. A., Gjesdal, C. G., ... Refsum, H. (2011). Dietary intake of protein is positively associated with percent body fat in middle-aged and older adults. The Journal of Nutrition, 141(3), 440446. https://doi.org/10.3945/jn.110.133710 [doi]

WHO. (2015). "Obesity and Overweight”. March 21, 2015. http://www.who.int/mediacentre/factsheets/fs311/en/.

Williams, M.H. (2002). Nutrition for Health, Fitness, and Sport. USA: The McgrawHill Companies, Inc.

Wittert, G.A. (2007). Obesity in Older Adults, dalam Morley, J.E, et al. (2007). Geriatric Nutrition. USA: CRC Press.

Zamboni, M., Mazzali, G., Zoico, E., Harris, T. B., Meigs, J. B., Di Francesco, V., ... Bosello, O. (2005). Health consequences of obesity in the elderly: A review of four unresolved questions. International Journal of Obesity, 29(9), 1011-1029. https://doi.org/10.1038/sj.ijo.0803005 